\title{
Environmental changes in the catchment of the Jarosławianka Stream recorded in mill pond deposits
}

\author{
Wacław Florek, Jerzy Jonczak, Monika Niska, Iwona Pasamonik \\ Department of Geoecology and Geoinformation, Institute of Geography and Regional Studies, Pomeranian University in Słupsk, \\ Partyzantów 27, 76-200 Słupsk, Poland, e-mail: wacflor@gmail.com (corresponding author), jonczak@apsl.edu.pl, monikaniska@wp.pl, \\ tylman84@gmail.com
}

\begin{abstract}
Interdisciplinary studies on environmental evolution during the last 650 years based on the analysis of mill pond deposits have been conducted in the valley of the Jarosławianka Stream (left-bank tributary of the River Wieprza). According to historical data, confirmed also by radiocarbon dating, the water mill was located in the valley in 1351 and operated until the 1960s. The sequence of stratified deposits with a thickness of up to about 2 metres was accumulated in mill pond basin during this period. The vertical variability in the physical and chemical properties of these deposits reflects temporal environmental changes in the catchment, particularly the intensity of chemical and mechanical denudation and human activity. Analysis of subfossil Cladocera suggests four phases in the development of the mill pond. Changing along with the intensity of the pond basin water flow, redox and nutritional conditions are reflected in the spatial variability of deposits, especially their textural parameters, $\mathrm{pH}$ and abundance in organic carbon, nitrogen and carbonates.
\end{abstract}

Key words: bottom deposits, mill ponds, environmental changes, Jarosławianka Stream, Sławno Plain

\section{Introduction}

Bottom deposits accumulated in the basins of mill ponds are a source of information about changes that occurred in the past in the areas of river drainage basins. Structural and textural characteristics of these deposits may reflect not only climate changes, but also allow for an evaluation of the land use (Szwarczewski 2003; Podgórski 2004). Investigation of the abovementioned characteristics supported by a paleobiological recognition usually also bring valuable information about the changes that were taking place in the environment of the reservoir and its surroundings.

The subject of the research conducted by the authors was a mill pond located in the lower reach of the Jarosławianka Stream, a small tributary of the lower River Wieprza, which joins the Wieprza between the villages Stary Kraków and Kowalewice. The related mill, according to Rosenow (1943), was founded in 1351, probably thanks to the Knights Hospitaller of St John of Jerusalem, who founded a church in the neighbouring Stary Kraków in approx. 1230; they also owned Stary Kraków, as well as many surrounding villages (Neitzel et al. 2007). The mill operated until 1960, when it became a victim of an organized campaign aimed at destroying watermills and associated damming equipment. Nowadays, only the remains of the foundations of the buildings and a partially destroyed dam are still visible.

\section{Study area}

The Jarosławianka Stream is a left-hand tributary of the lower Wieprza with a constantly drained catchment area of $5.74 \mathrm{~km}^{2}$ (Fig. 1), which was formed in the late Pleistocene within a moraine plateau extended with glaciolacustrine deposits (Florek and Tylman 2013, Jonczak and Florek 2013). This area has been settled and utilized with varying intensity for a long time (Rączkowski and Banaszek 2013). During 


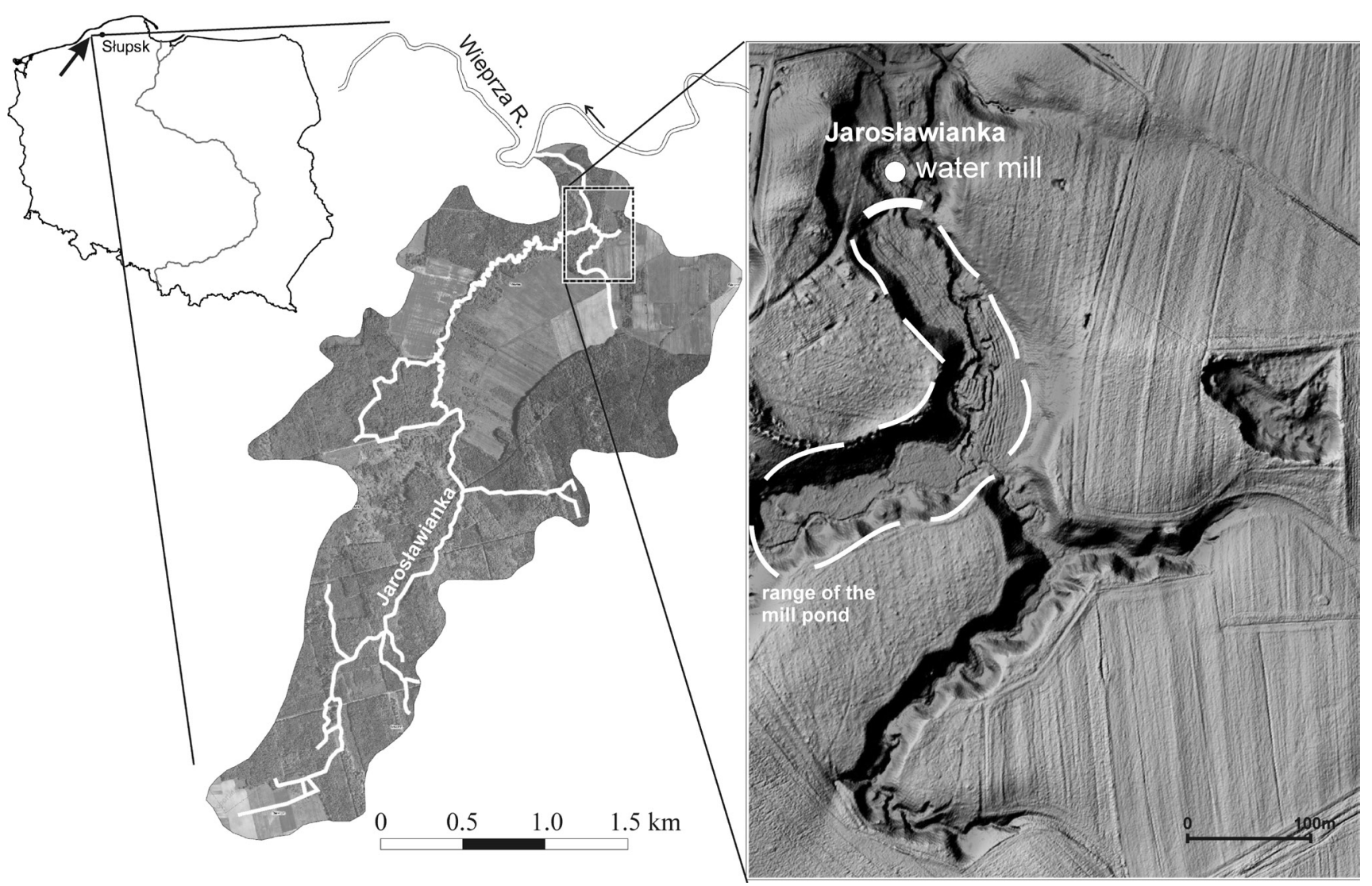

Fig. 1. Location of the investigated mill pond in the Jarosławianka Stream valley (Sławno Plain)

the year, a discharge intensity of the order of several dozen $1 / \mathrm{s}$ is predominant, while in the spring there are floods caused by a downflow of thaw and rain waters with a flow rate of up to $1500 \mathrm{dm}^{3} \mathrm{~s}^{-1}$ (Florek et al. 2009). The middle and lower sections of the Jarosławianka Stream valley are characterized by a deep incision of even more than $10 \mathrm{~m}$ into the surface of the moraine plateau, the surface of which here is at the elevation of 20-22 $\mathrm{m}$ a.s.l., while the bottom of the valley is at the elevation of 14.5-11.0 m a.s.l. Distinctive features of this section of the valley are the lack of preserved terrace levels, and typically a significant inclination of its slopes of $7^{\circ}$ to $15^{\circ}$, as well as a flattening of the bottom of the valley (Fig. 2, Florek and Tylman 2013), covered with recently planted alders (Fig. 3). A flat moraine plateau, which constitutes the northern part of Sławno Plain is built of silty-clay glaciolacustrine sediments and brown, decalcified tills, underlain with grey, compact, carbonate tills (Jonczak and Florek 2013). On the border of tills and younger glaciolacustrine deposits, or within the latter, there are sand interbeddings, which are not very thick, consti- tuting an aquifer. The water which constitutes a base for supplying the stream, and forms numerous small spring niches, flows from these layers along the slopes of the valley (Jonczak and Kowalkowski 2013). The bottom of the valley is covered by pavement on which lie sands of various textural parameters, with a silty addition of a thickness which does not usually exceed $1 \mathrm{~m}$. Within a section of several hundred metres, and within reach of the backwater from the currently non-existant mill, fluvial deposits are covered with a 1-2 m thick layer of silts, which were deposited in the area of the former mill pond (Fig. 4). Near the slopes of the valley and in the upper reach of the backwater from the mill pond, these deposits are irregularly stratified (Fig. 5). In the central and lower part of the mill pond, there are a few light laminae of fine sand, or silt. Muddy gley soils that contrast with peaty gley soils, occurring in inactive meanders, and active spring niches, and silty gley soils occupying the remaining part of the bottom of the Jarosławianka valley above the reach of the backwater from the mill pond, developed on the base of these deposits (Fig. 4, Jonczak and Kowalkowski 2013). 


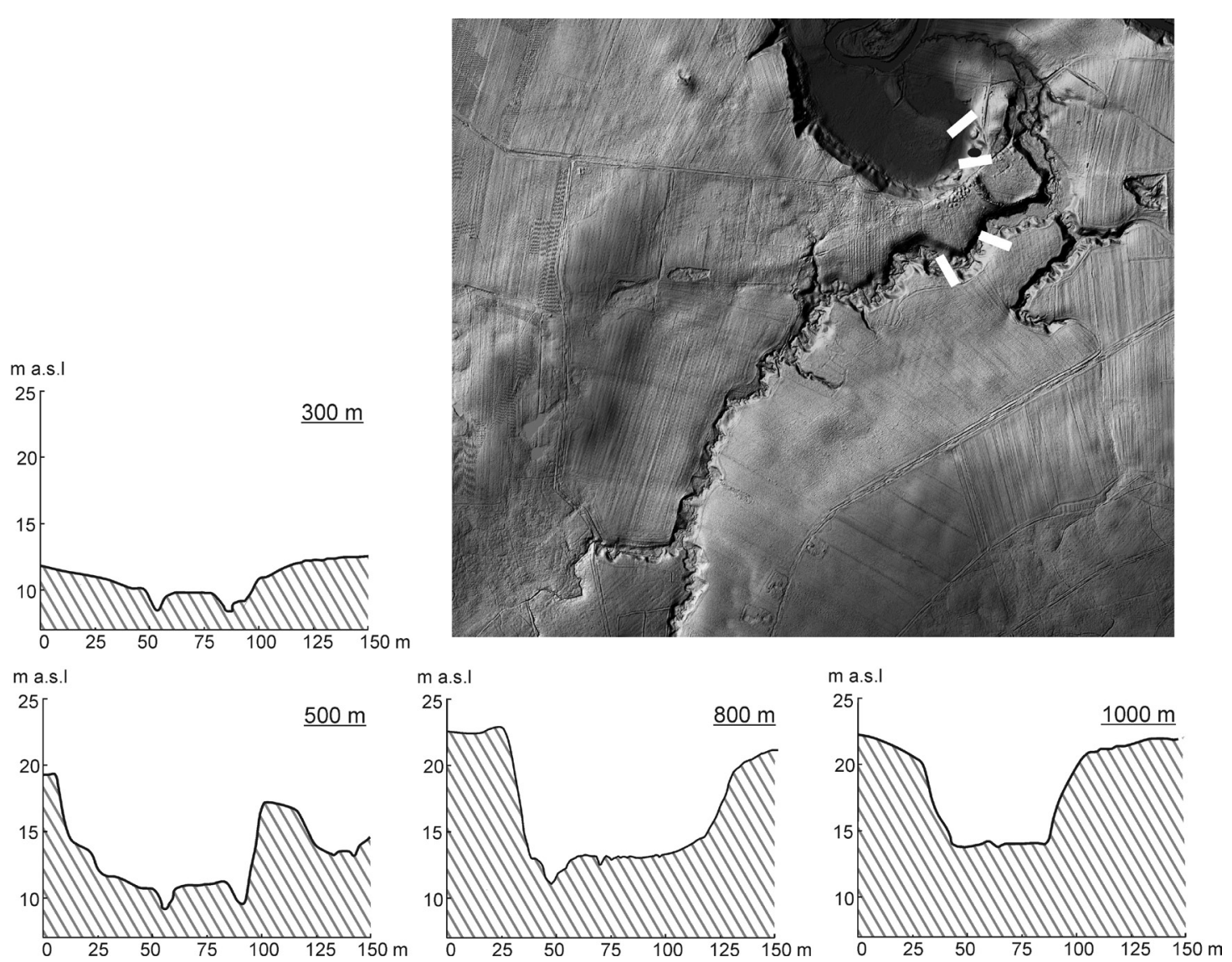

Fig. 2. Transverse profiles of the lower part of the Jarosławianka Stream valley (from Florek and Tylman (2013): partly modified)

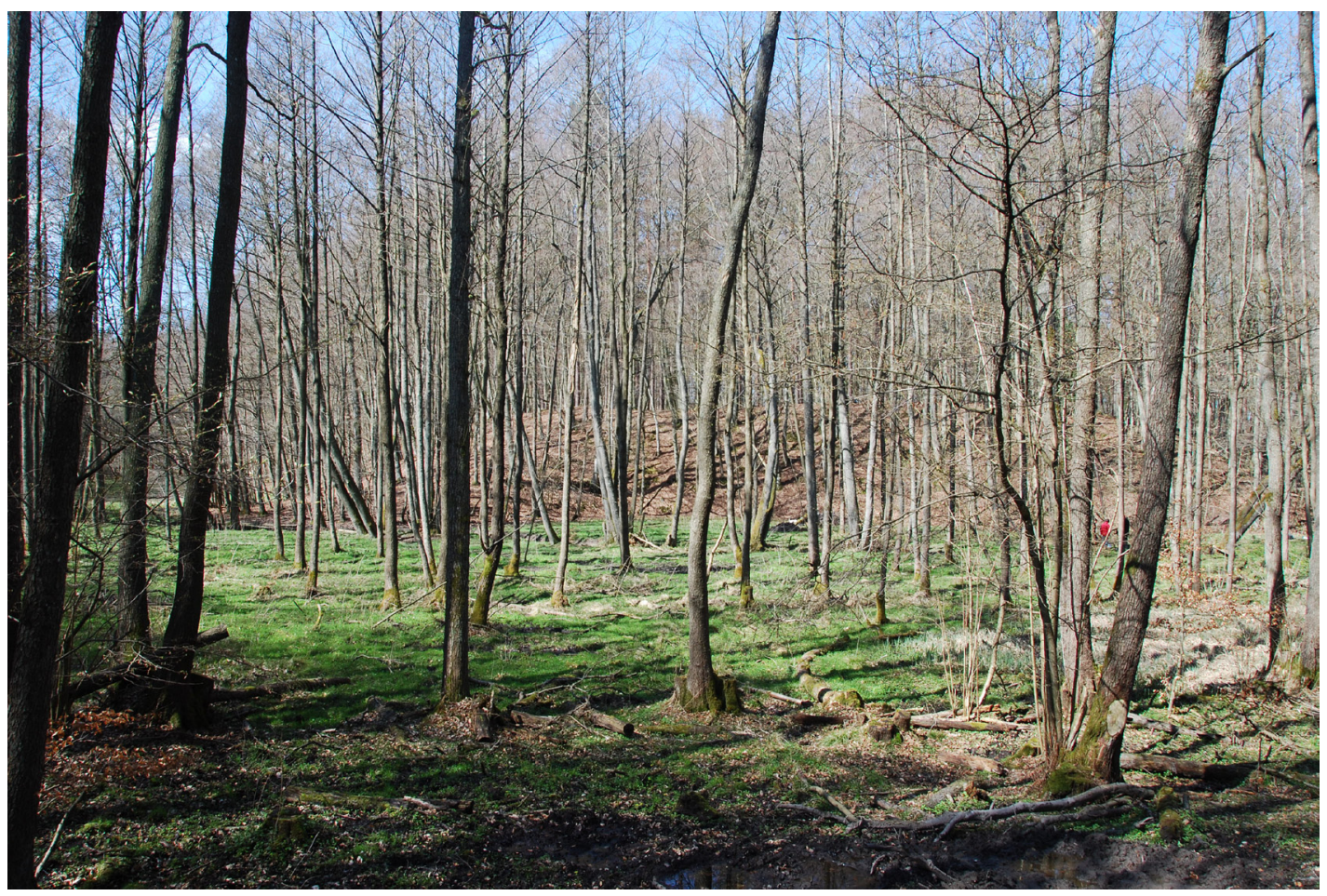

Fig. 3. The bottom of the former mill pond (0.6-0.8 km of the Jarosławianka Stream) afforested with alder (phot. W. Florek; May 2012) 


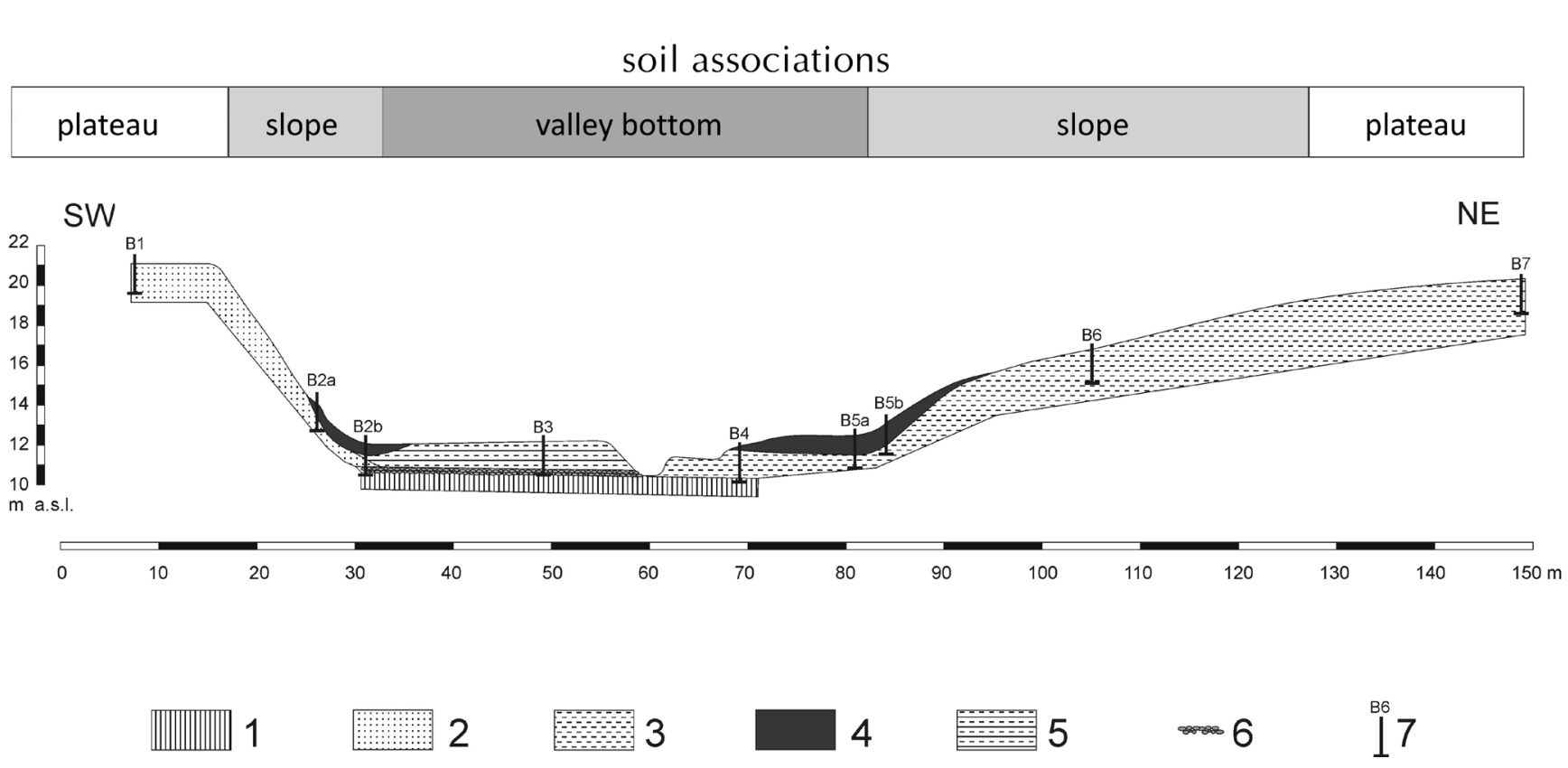

Fig. 4. A geological and soil cross-section of the Jarosławianka Stream valley and mill pond deposits: 1 - moraine till, 2 - sands, 3 - glaciolacustrine muds, 5 - muddy deposits of the mill pond, 6 - pavement, 7 - the location of outcrops (from Jonczak and Kowalkowski 2013: partly modified).

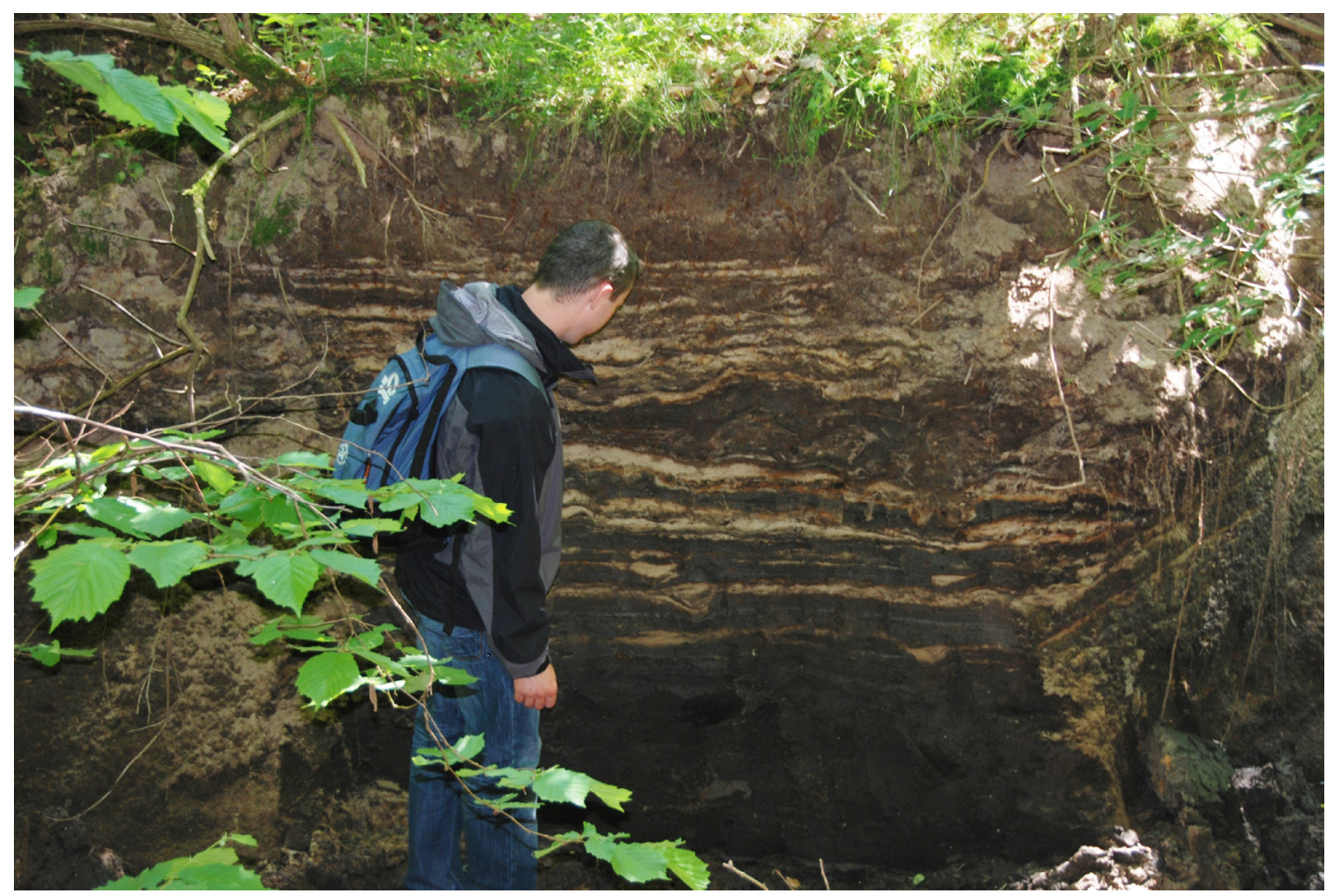

Fig. 5. Stratified mill pond deposits in the Jarosławianka Stream valley (phot. W. Florek; May 2012).

\section{Results}

Fluvial sands with interbeddings of peat, on which peaty gley soils developed, occur below the mill pond deposits. Their roof age was estimated using a ra- diocarbon method to be $750 \pm 50 \mathrm{BP}$ (MKL-1335) (Jonczak and Florek 2013). Whereas the bed part of silty deposits, interpreted as being deposited in the mill pond,

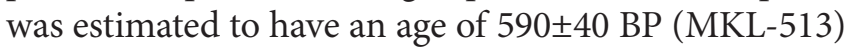
(Jonczak and Florek 2013). These dates perfectly match 
the historical data, according to which the water mill was established in 1351. It is difficult to determine now whether the mill pond deposits represent an unbroken sequence of the entire operating period of the mill; this requires further, more detailed studies (Jonczak and Florek 2013). The mill pond deposits are partially covered with a layer of sandy-silty deposits, which constitute a diamicton of the material originating from regulatory works carried out after 1960. Silts filling the pond were subjected to an investigation of the fauna of Cladocera, which was performed in accordance with commonly applied procedures (Niska 2013). The results of this investigation confirmed that the investigated basin was a shallow reservoir, whose Cladocera species composition was dominated by littoral species. The largest group of species were Cladocera associated with the silty bottom, dwelling among aquatic plants. The reservoir was characterized by moderately warm water, as indicated by the occurrence of species that prefer a higher water temperature (it is also suggested by cartographic and iconographic materials showing that the Jarosławianka Stream valley in the vicinity of the reservoir was deforested), and high productivity, as evidenced by the occurrence of eutrophic species. The Cladocera species occurring in the reservoir are characterized by a high environmental tolerance. Some Cladocera dwelling in the pond also occur in the riverside zone, which proves their resistance to turbulent conditions and rapid flow of water. The central part of the investigated profile is almost devoid of Cladocera remains. This was probably caused by the decrease in water $\mathrm{pH}$, associated with as yet unidentified environmental changes to the drainage basin, or the pond. Also, in the upper part of the investigated profile (Fig. 6), no presence of Cladocera remains was found. It can be assumed that it was associated with the period of a significant filling of the pond with deposits, and a transformation of the environment into the bottom of a river valley, flooded only periodically, which did not favour the development of fauna of Cladocera (Niska 2013).

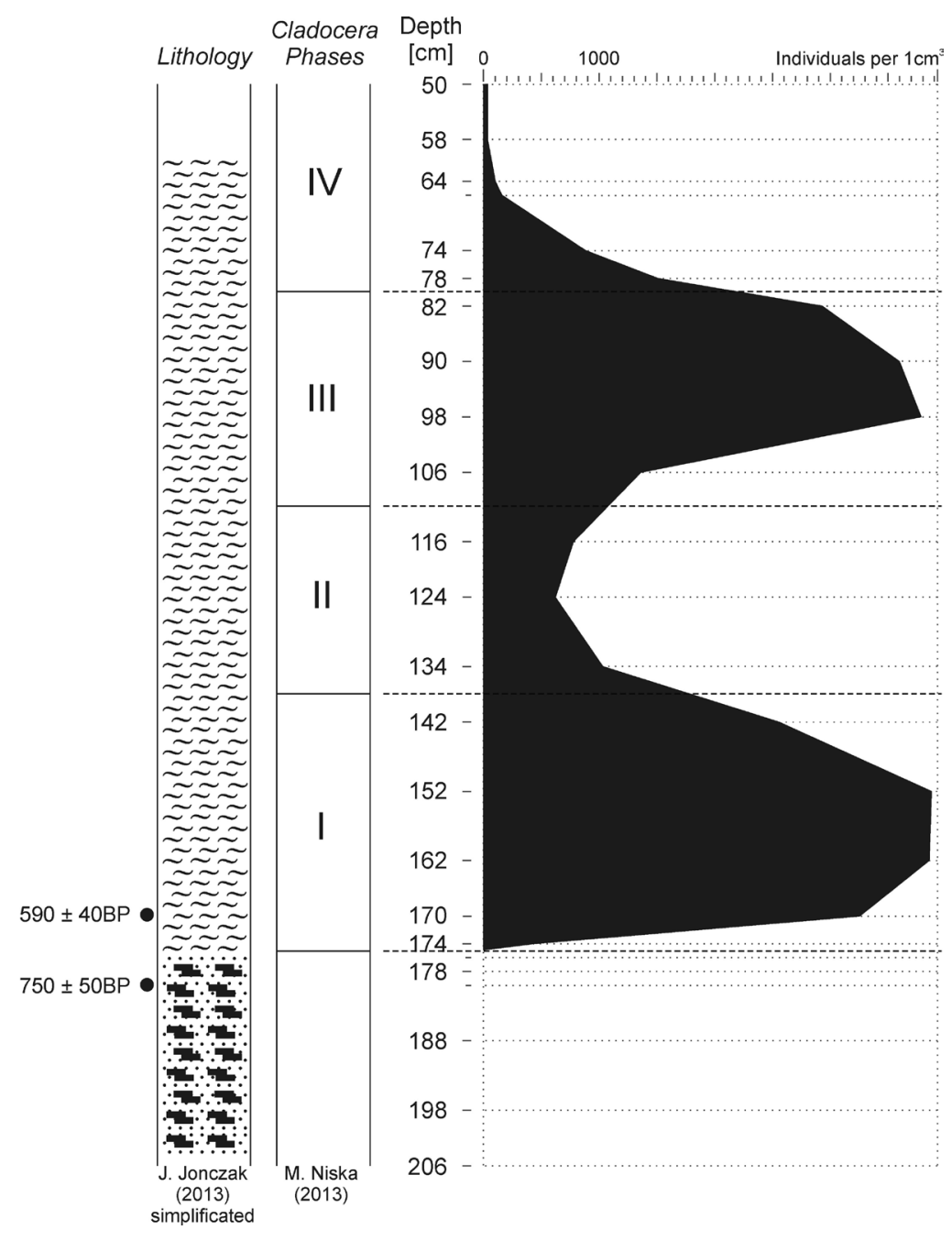

Fig. 6. Total number of Cladocera individuals in $1 \mathrm{~cm}^{3}$ of fresh deposit (profile 2, mill pond, and the Jarosławianka Stream) (Niska 2013) 


\section{Conclusions}

The investigations conducted to date confirmed that mill pond deposits are located within a several hundred metre-long, lower section of the Jarosławianka Stream valley. A water mill operated here from the Middle Ages (and more precisely from 1351), which is well documented by historical and cartographic testimonies, as well as radiocarbon dating. The vertical variability in the physical and chemical properties of these deposits reflects temporal environmental changes in the catchment, particularly the intensity of chemical and mechanical denudation and human activity. Among the studies conducted to date, the largest amount of information was provided by Cladocera analysis, the results of which showed that the history of the pond can be divided into four periods. Changing along with the intensity of the pond basin water flow, redox and nutritional conditions are reflected in the spatial variability of deposits, especially their textural parameters, $\mathrm{pH}$ and abundance in organic carbon, nitrogen and carbonates.

The dates of their occurrence require further isotope dating. It is also necessary to conduct detailed geochemical studies of the mill pond deposits, as well as other deposits constituting the Jarosławianka Stream catchment. This will enable a reconstruction of its history in the times when the mill pond existed.

\section{References}

Florek W., Jonczak J., Princ C., 2009, The impact of snowmelt-rain flood on runoff denudation from small lowland catchments (on example of left-bank tributaries of lower Wieprza), Baltic Coastal Zone 13B: 67-78.

Florek W., Tylman I., 2013, Skaning laserowy w badaniach morfologicznych małych dolin rzecznych (przypadek doliny Jarosławianki) (Laser scanning in morphological research on small valleys (Jarosławianka valley case study), [in:] Jonczak J., Florek W. (eds), Środowisko glebotwórcze i gleby dolin rzecznych (Soil-forming environment and soils of river valleys), Bogucki Wydaw. Nauk., Poznań-Słupsk: 19-32 (in Polish, English summary).

Jonczak J., Florek W., 2013, Wiek i właściwości gleb wykształconych z osadów stawu młyńskiego w dolinie Jarosławianki (Równina Sławieńska) (Age and properties of the soils formed from mill-pond deposits in the valley of Jarosławianka Creek (Northern Poland)), [in:] Jonczak J., Florek W. (eds), Środowisko glebotwórcze i gleby dolin rzecznych (Soil-forming environment and soils of river valleys), Bogucki Wydaw. Nauk., PoznańSłupsk: 33-40 (in Polish, English summary).
Jonczak J., Kowalkowski A., 2013, Geneza, zróżnicowanie przestrzenne i właściwości poligenetycznych glab zlewni Jarosławianki (Genesis, spatial variability and properties of the polygenetic soils of Jarosławianka catchment), [in:] Jonczak J., Florek W. (eds), Środowisko glebotwórcze i gleby dolin rzecznych (Soil-forming environment and soils of river valleys), Bogucki Wydaw. Nauk., Poznań-Słupsk: 41-56 (in Polish, English summary).

Neitzel U., Schmidt F., Sielaff M., 2007, Die Mühlechronik des Kreise Schlawe (Ostpommern), Genealogische Schriften für Ostpommern 4: 1-434.

Niska M., 2013, Ewolucja stawu młyńskiego w dolinie Jarosławianki w świetle analizy kopalnych szczątków Cladocera (Crustacea) (Evolution of the mill-pond in the valley of Jarosławianka Creek based on subfossil Cladocera (Crustacea) analysis), [in:] Jonczak J., Florek W. (eds), Środowisko glebotwórcze i gleby dolin rzecznych (Soil-forming environment and soils of river valleys), Bogucki Wydaw. Nauk., Poznań-Słupsk: 103-112 (in Polish, English summary).

Podgórski Z., 2004, Wpływ budowy i funkcjonowania młynów wodnych na rzeźbę i wody powierzchniowe Pojezierza Chełmińskiego i przyległych części dolin Wisły i Drwęcy (The influence of the construction and functioning of watermills on the relief of the land and surface water of Chelmno Lakeland and the adjoining parts of the Vistula and Drwęca valleys), Wydaw. UMK, Toruń, pp. 203 (in Polish).

Rączkowski W., Banaszek Ł., 2013, Osadnictwo w rejonie Jarosławianki - problemy badawcze (Settlement pattern in the catchment of Jarosławianka river - research issues), [in:] Jonczak J., Florek W. (eds), Środowisko glebotwórcze i gleby dolin rzecznych (Soil-forming environment and soils of river valleys), Bogucki Wydaw. Nauk., Poznań-Słupsk: 113-121 (in Polish, English summary).

Rosenow K., 1943, Die Wassermühlen im Kreise Schlawe, Ostpommersche Heimat. Beilage der Zeitung für Ostpommern Nr. 25, 26, 28.

Szwarczewski P., 2003, Zapis naturalnych i antropogenicznych zmian środowiska przyrodniczego w okolicy Żyrardowa na przykładzie osadów wypełniających nieckę stawu młyńskiego (Record of the natural and anthropogenic environmental changes in the vicinity of the town Żyrardów based on the example of bottom sediments filling the mill pond basin), [in:] Waga J.M., Kocel K. (eds), Człowiek w środowisku przyrodniczym - zapis działalności (Man and the natural environment - record of activity], PTG Oddział Katowicki, Sosnowiec: 213-219 (in Polish). 